\title{
ADDIE SEBAGAI MODEL PENGEMBANGAN MEDIA INSTRUKSIONAL EDUKATIF (MIE) MATA KULIAH KURIKULUM DAN PENGAJARAN
}

\author{
Nyoman Sugihartini ${ }^{11}$, Kadek Yudiana ${ }^{2)}$ \\ ${ }^{1}$ Fakultas Teknik dan Kejuruan, Universitas Pendidikan Ganesha \\ email: sugihartini@undiksha.ac.id \\ ${ }^{2}$ Fakultas IImu Pendidikan, Universitas Pendidikan Ganesha \\ email: yudix19665@yahoo.com
}

\begin{abstract}
Abstrak
Mata kuliah kurikulum dan pengajaran belum memiliki media pembelajaran yang dapat mendukung implementasi blanded learning. Penelitian ini bertujuan untuk: merancang dan mengimplementasikan Media Instruksional Edukatif (MIE) mata kuliah Kurikulum dan Pengajaran. Model pengembangan yang digunakan adalah model ADDIE yang terdiri dari lima tahapan yaitu 1) analisis, 2) perancangan, 3) pengembangan, 4) implementasi dan 5) evaluasi. Pada tahap analisis, dilakukan analisa terkait dengan kebutuhan system dan analisis TIU/TIK mata kuliah kurikulum dan pengajaran sesuai dengan silabus/SAP. Berdasarkan hasil analisis siabus mata materi pada MIE dibagi menjadi 7 bab. Pada tahap perancangan dilakukan perancangan sistematika modul kurikulum dan pengajaran serta dilakukan tahapan rancangan sistem, database, dan interface. Tahap pengembangan merupakan keberlanjutan dari apa yang sudah dirancang, yakni menyusun konten sesuai dengan silabus/SAP, dalam hal ini LMS (Learning Management System) yang digunakan adalah Moodle. Tahap Implementasi adalah memasukkan konten ke dalam Moodle dengan penyajian proses pembelajaran mengikuti tahapan model pembelajaran project based learning $(\mathrm{PjBL})$.
\end{abstract}

Kata kunci: e-modul, kurikulum dan pengajaran, CAI

\begin{abstract}
Curriculum and teaching courses do not have learning media that can support the implementation of blanded learning. This study aimed to: design and implement Educative Instructional Media courses in Curriculum and Teaching. The development model used is the ADDIE model consisting of five stages: 1) analysis, 2) design, 3) development, 4) implementation and 5) evaluation. In the analysis phase, analysis is done related to the needs of the system and the analysis of learning objectives curriculum and teaching courses in accordance with the syllabus. Based on the analysis of the material was divided into 7 chapters. At the design stage, a systematic design of curriculum and teaching modules is carried out and the system, database, and interface design stages are carried out. Development stage is the continuity of what has been designed, compiling the content in accordance with the syllabus, in this case LMS (Learning Management System) used Moodle. The implementation phase is to enter content into Moodle by presenting the learning process following the stages of the project based learning (PjBL) model.
\end{abstract}

Keywords: e-modul, curriculum and teaching, CAI 


\section{PENDAHULUAN}

Pada hakikatnya kegiatan belajar mengajar adalah suatu proses komunikasi. Komunikasi merupakan suatu interaksi dua orang atau lebih yang bertujuan untuk menyampaikan pesan atau informasi. Agar penyampaian pesan atau informasi tersebut dapat dilakukan dengan baik perlu dibantu dengan media. Media dapat membantu mengurangi atau bahkan tidak terjadi kesalahan dalam proses komunikasi. Sehingga media dapat membuat proses pembelajaran menjadi lebih efektif. Media yang digunakan dalam proses belajar mengajar dikenal dengan istilah Media Instruksional Edukatif atau sering disingkat dengan MIE. "Media instruksional edukatif merupakan sarana komunikasi dalam proses belajar mengajar yang berupa perangkat keras maupun perangkat lunak untuk mencapai proses dan hasil instruksional secara efektif dan efisien, serta tujuan instruksional dapat dicapai dengan mudah" (Sugihartini, 2016).

$\mathrm{Di}$ era revormasi industri 4.0 kemajuan Teknologi Informasi dan Komunikasi sangat pesat, serta berpengaruh pada proses pengembangan jenis media instruksional edukatif yang digunakan dalam pembelajaran. Salah satunya berbentuk e-modul (Modul elektronik). "E-modul merupakan pengembangan modul cetak dalam bentuk digital yang banyak mengadaptasi dari modul cetak. kelebihan e-modul, diantaranya: tercipta suasana pembelajaran yang menyenangkan, dapat meningkatkan hasil belajar, mempermudah dalam memecahkan masalah dilengkapi tes/kuis formatif yang memungkinkan umpan balik otomatis". (Damarsasi, Soeprodjo, \& Saptorini, 2013). Selain itu e-modul juga memiliki peran, Damarsasi, dkk (2013) menyebutkan diantaranya adalah "(1) menghemat waktu guru mengajar, (2) mengubah peran guru dari seorang pengajar menjadi seorang fasilitator, (3) meningkatkan proses pembelajaran menjadi lebih efektif dan interaktif". Dalam pembelajaran individual, menurut Riyadi (2017) "e-modul memiliki peran (1) sebagai media utama dalam proses pembelajaran, (2) alat yang digunakan untuk menyusun dan mengawasi proses siswa memperoleh informasi, penunjang media pembelajaran individual".

Pembelajaran dengan e-modul akan sangat membantu menyampaikan materi yang bersifat teori seperti pada mata kuliah Kurikulum dan Pengajaran. Mata kuliah Kurikulum dan pengajaran merupakan mata kuliah penting dikuasai oleh Mahasiswa calon guru dan menjadi salah satu prasyarat untuk mengikuti program PPL real. Melalui penelitian ini, kami selaku pengajar mata kuliah Kurikulum dan Pengajaran mencoba untuk mengembangkan media instruksional edukatif jenis e-modul untuk mengemas materi mata kuliah Kurikulum dan Pembelajaran mengingat begitu banyak manfaatnya sehingga dapat membantu mengoptimalkan proses perkuliahan.

\section{Media Instruksional Edukatif}

Secara harfiah, kata media berasal dari kata Latin, yang merupakan bentuk jamak dari kata medium atau tengah. Secara harfiah kata tersebut mempunyai makna pengantar atau perantara. Menurut National Education Asociation, menjelaskan bahwa Media merupakan sarana komunikasi dalam bentuk cetak maupun audio visual, termasuk teknologi perangkat kerasnya (Ali, 2009). Sedangkan istilah intruksional berasal dari istilah bahasa inggris yaitu instruction, yang menggambarkan proses pembelajaran. Makna edukatif menurut Kamus Besar Bahasa Indonesia (KBBI), "edukatif adalah bersifat mendidik atau berkenaan dengan pendidikan. Sedangkan arti kata pendidikan merupakan proses perubahan sikap dan perilaku (tata laku) seseorang atau sekelompok orang dalam usaha mendewasakan manusia atau seseorang melalui upaya pengajaran dan pelatihan". 
Jadi dapat disimpulkan bahwa media pembelajaran edukatif adalah segala sesuatu yang dapat merangsang siswa atau peserta didik untuk belajar sehingga terjadi perubahan tingkah laku pada diri siswa (peserta didik) sesuai dengan tujuan tertentu. sebenarnya Istilah Media Instruksional Edukatif digunakan atas dasar indikator atau dimensi suatu proses instruksional yang sebenarnya dalam pembelajaran mencakup unsur-unsur normatif. Selain itu, Media instruksional edukatif juga merupakan sarana komunikasi dalam proses belajar mengajar yang berupa perangkat keras (Hardware) maupun perangkat lunak (Software) untuk mencapai proses dan hasil instruksional secara efektif dan efisien, serta tujuan instruksional dapat dicapai dengan mudah serta sesuai harapan.

Secara umum dapat dijabarkan peranan media instruksional edukatif dalam pencapaian tujuan pembelajaran antara lain:

a. Dapat mengatasi keterbatasan ruang atau kelas, waktu, tenaga (SDM) dan daya indera

b. Dapat menimbulkan atau meningkatkan gairah (semangat) belajar, interaksi lebih langsung antara siswa (peserta didik) dengan sumber belajar

c. Memungkinkan (menciptakan) anak belajar mandiri

d. Dapat memberi rangsangan yang sama, mempersamakan pengalaman (pemahaman) dan menimbulkan persepsi yang sama.

e. kualitas proses pembelajaran dapat ditingkatkan

f. proses pembelajaran dapat berlangsung kapanpun dan dimanapun diperlukan (tidak terbatas ruang dan waktu)

g. sikap positif siswa (peserta didik) terhadap materi pembelajaran serta proses pembelajaran dapat ditingkatkan.
Di era revolusi industri 4.0 sekarang ini, Perkembangan Teknologi yang semakin pesat, juga mempengaruhi jenis media instruksional edukatif yang dikembangkan. Salah satunya adalah berbasis teknologi internet, misalnya dalam bentuk e-learning ataupun e-modul.

\section{Kurikulum dan Pengajaran}

Mata kuliah kurikulum dan pengajaran merupakan mata kuliah yang mempelajari konsep dan pengertian kurikulum, serta kaitanya dengan proses pengajaran. Kurikulum dan pengajaran merupakan satu kesatuan konsep yang saling berhubungan. Dimana kurikulum merupakan acuan dalam proses pengajaran yang dilakukan oleh setiap Pendidik (Guru maupun Dosen). Dalam UU No 20 Tahun 2003 dijelaskan bahwa "kurikulum merupakan seperangkat rencana dan pengaturan mengenai tujuan, isi, dan bahan pelajaran serta cara yang digunakan sebagai pedoman penyelenggaraan kegiatan pembelajaran untuk mencapai tujuan pendidikan tertentu. Sedangkan pengertian Pengajaran merupakan perpaduan dari dua aktivitas, yaitu aktivitas mengajar dan aktivitas belajar. Aktivitas mengajar menyangkut peranan seorang guru (pendidika) dalam konteks mengupayakan terciptanya jalinan komunikasi harmonis antara mengajar itu sendiri dengan belajar. Jalinan komunikasi yang harmonis inilah yang menjadi indicator atau tolak ukur suatu aktivitas proses pengajaran itu akan berjalan dengan baik sesuai prosedur".

\section{LMS Moodle sebagai Implementasi MIE}

Moodle merupakan singkatan dari Modular Object Oriented Dynamic Learning Environment yang berarti lingkungan belajar dinamis dengan menggunakan modul berorientasi objek atau merupakan paket lingkungan pendidikan berbasis web yang dinamis dan dikembangkan dengan konsep berorientasi objek. Selain penggunaannya 
yang cukup mudah, Moodle juga memiliki berbagai fasilitas yang dapat berguna mendukung kegiatan pembelajaran. Fasilitas yang terdapat pada Moodle antara lain Assignment,Chat, Forum, Quiz, dan Survey (Adiputra, 2014). Menurut Amiroh (2012) penjelasan untuk masing masing "fasilitas pada moodle diantaranya: (a) Assignment atau penugasan (tugas) digunakan untuk memberikan penugasan kepada peserta pembelajaran (siswa) secara online. Peserta pembelajaran (siswa) dapat mengakses materi tugas dan mengumpulkan tugas dengan cara mengirimkan file hasil pekerjaan siswa (peserta didik. (b) Chat, fasilitas ini digunakan oleh pengajar (guru) dan peserta pembelajaran (siswa) untuk saling berinteraksi secara online dengan cara berdialog teks (percakapan online). (c) Forum merupakan tempat (forum) diskusi secara online antara pengajar dan peserta pembelajaran yang membahas topik-topik yang berhubungan dengan materi pembelajaran. (d) Quiz, fasilitas ini digunakan oleh pengajar (guru) untuk melakukan ujian atau tes secara online (online test). (e) Survey (survei), merupakan fasilitas yang digunakan untuk melakukan jajak pendapat".

E-modul dalam penelitian ini akan dikembangkan dengan menggunakan software Moodle. Moodle merupakan aplikasi LMS (learning management system) terbaik dari segi fitur dibandingkan dengan jenis LMS lainnya. Pada penelitian pengembangan ini Moodle berfungsi sebagai wadah untuk menempatkan berbagai materi pelajaran/course (kurikulum dan pengajaran) yang akan dikemas dengan tampilan user friendly sesuai dengan kebutuhan guru (pendidik) dan siswa (peserta didik). Dengan berbagai fitur dan kelebihan Moodle, e-modul yang dikembangkan bukan hanya menampilkan materi berupa teks dan gambar, tetapi juga disertai dengan bantuan media CAI (computer assissted instruction) berupa teks, penugasan, quiz, video tutorial, simulasi, atau Drill and Practice pada setiap kegiatan belajar. Berbagai
fiturMoodle yang akan digunakan seperti fasilitas forum, assignment, quiz,chatting, dan beberapa fasilitas Moodle lain yang mendukung proses pembelajaran. Tampilan desain pembelajaran dalam Moodle dikembangkan sendiri oleh peneliti dan untuk tahapan pembelajaran dalam emodul berbasis project based learning $(P j B L)$ yakni proses pembelajaran disertai dengan projek-projek yang harus dikerjakan oleh peserta didik.

\section{METODE}

Penelitian pengembangan MIE ini menggunakan model ADDIE yang merupakan singkatan dari Analyze, Design, Development, Implementation, Evaluation. Model ini dipilih karena model ADDIE sering digunakan karena tahapan model ADDIE menggambarkan pendekatan sistematis untuk pengembangan instruksional. Adapun prosedur pengembangan produk dengan model ADDIE dapat dilihat pada gambar 1.

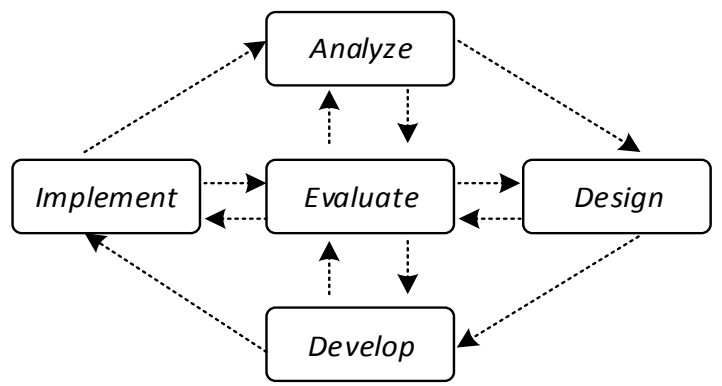

Gambar 1. Tahapan Model ADDIE

\section{a. Tahap Analyze (analisis)}

Secara rinci pada tahap analisis terdapat dua hal yang dilakukan yaitu (1) analisis kebutuhan isi/konten berdasarkan silabus (kurikulum) dan (2) analisis kebutuhan perangkat lunak (software).

\section{a. Analisis Kebutuhan Isi/ Konten}

Pada tahap ini dilakukan kegiatan identifikasi materi pengembangan sesuai silabus untuk materi perkuliahan Kurikulum dan Pengajaran. Selain itu juga dilakukan analisis karakteristik yakni, dengan 
menganalisis silabus/SAP (satuan acara perkuliahan) pada mata kuliah Kurikulum dan Pengajaran yang berlaku.

b. Analisis Kebutuhan Software (Perangkat Lunak)

Analisis kebutuhan (need analysis) pada tahap ini bertujuan untuk melakukan analisa kebutuhan fungsiona sisteml, analisis kebutuhan non fungsional, dan analisa sistem yang diperlukan dan mampu dilakukan oleh aplikasi perangkat lunak Moodle.

\section{b. Tahap Design (perancangan)}

Kegiatan pada tahap design atau perancangan ini terdiri dari perancangan modul, perancangan interface, dan perancangan pengembangan e-modul.

\section{c. Tahap Development (pengembangan)}

Langkah pengembangan pada tahap ini meliputi beberapa kegiatan, diantaranya: mengembangkan bahan instruksional seuai silabus/SAP, penyusunan materi sesuai silabus, dan evaluasi (meliputi: tugas, soal latihan dll), pengembangan Moodle, pengembangan media e-Modul dan fitur pendukung pembelajaran yang diperlukan dosen dan mahasiswa. Hasil pada tahap development ini adalah sebuah produk modul ajar dan e-modul yang sudah terstruktur sesuai dengan kompetensi yang berlaku serta angket untuk mengukur validitas dan respon subjek penelitian.

d. Tahap (implementasi)

Implementation

Dalam melakukan implementasi penggunaan e-modul, adapun beberapa spesifikasi minimal perangkat lunak dan perangkat keras yang dibutuhkan untuk e-modul Kurikulum dan Pengajaran, yaitu sebagai berikut.

a. Kebutuhan software (Perangkat Lunak)
1. OperatingSystem:Wind ows XP Service Pack 3

2. Internet Browser : Firefox, Google Chrome

3. Adobe Flash Player

4. Adobe Reader

b. Kebutuhan minimal Perangkat Keras (hardware) yang dibutuhkan, meliputi:

1. Monitor with $1024 \mathrm{x}$ 728-pixel resolution

2. 512 MB RAM

3. Processor Pentium IV $3.0 \mathrm{GHz}$

4. VGA minimal128mb

5. 1 GBFree Hardisk Space

6. Sound card and speakers/ headset

\section{e. Tahap Evaluation (evaluasi)}

Evaluation atau Evaluasi adalah proses untuk melihat (melakukan evaluasi) apakah sistem pembelajaran yang sedang dibangun berhasil, sesuai dengan harapan pengembangan diawal atau tidak. Sebenarnya tahap evaluasi bisa terjadi pada setiap akhir tahapan pada keempat fase atau tahap di atas. Evaluasi yang terjadi pada setiap empat tahap di atas itu dinamakan evaluasi formatif, yang bertujuan untuk melakukan perbaikan dengan secepatnya. Tahap Evaluasi merupakan langkah terakhir dari model desain sistem pembelajaran ADDIE. Evaluasi adalah sebuah proses yang dilakukan untuk memberikan nilai terhadap program pembelajaran (Trisiana dan Wartoyo, 2016)

Pada tahap ini hanya digunakan evaluasi formatif yang bertujuan untuk mengumpulkan data tentang efektivitas dan efisiensi MIE untuk mencapai tujuan yang ditetapkan. Data tersebut dimaksudkan untuk memperbaiki dan menyempurnakan MIE yang bersangkutan agar lebih efektif dan efisien. Evaluasi formatif terdiri dari review ahli, evaluasi perorangan, evaluasi kelompok kecil, dan uji lapangan. 
Setelah produk dinyatakan layak oleh para ahli maka akan dilanjutkan ke tahap uji coba perorangan, uji kelompok kecil, dan uji lapangan. Apabila dalam uji coba tersebut masih ditemukan kekurangan, maka perlu dilakukan tahap evaluasi kembali untuk melakukan penyempurnaan MIE yang dikembangkan. Kegiatan evaluasi pada tahap ini bukan hanya terbatas dilakukan ketika perancangan, pengembangan, dan implementasi produk, tapi juga dilakukan ketika melakukan semua tahap pengembangan model ADDIE

\section{HASIL DAN PEMBAHASAN}

Media instruksional edukatif mata kuliah Kurikulum dan Pengajaran telah dipublish di bawah domain e-learning undiksha, dapat diakses pada alamat http://elearning.undiksha.ac.id. Media ini memiliki tiga level pengguna yakni: Admin, Dosen, dan Mahasiswa. Adapaun aktivitas-aktivitas yang bisa dilakukan oleh ketiga level pengguna tersebut dapat dilihat pada usecase sistem (gambar 2)

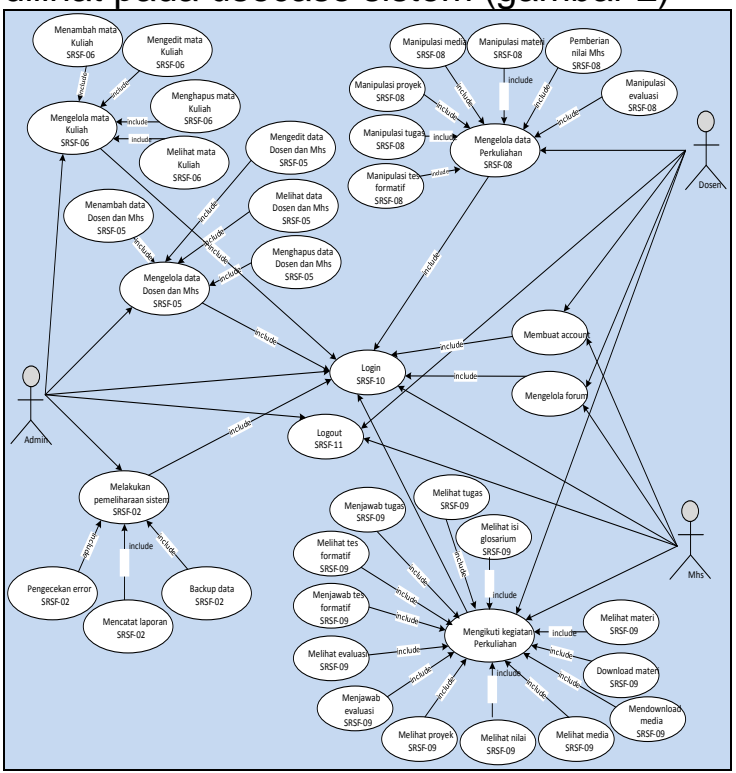

Gambar 2. Usecase sistem

Adapun aktivitas yang bisa dilakukan oleh Mahasiswa adalah melakukan login ke sistem, mengikuti pembelajaran, berdiskusi di forum, mengirim tugas. Sedangkan Dosen bisa melakukan absensi perkuliahan mahasiswa, update materi perkuliahan, update tugas mahasiswa, penilaian, diskusi di forum.
Sedangkan level admin bisa melakukan semua kegiatan yang dilakukan oleh mahasiswa dan Dosen. Kelebihan Admin adalah bisa mengelola account baik level mahasiswa maupun Dosen.

Adapun tampilan "Home" sistem MIE mata kuliah Kurikulum dan pengajaran dapat dilihat pada gambar 3 .

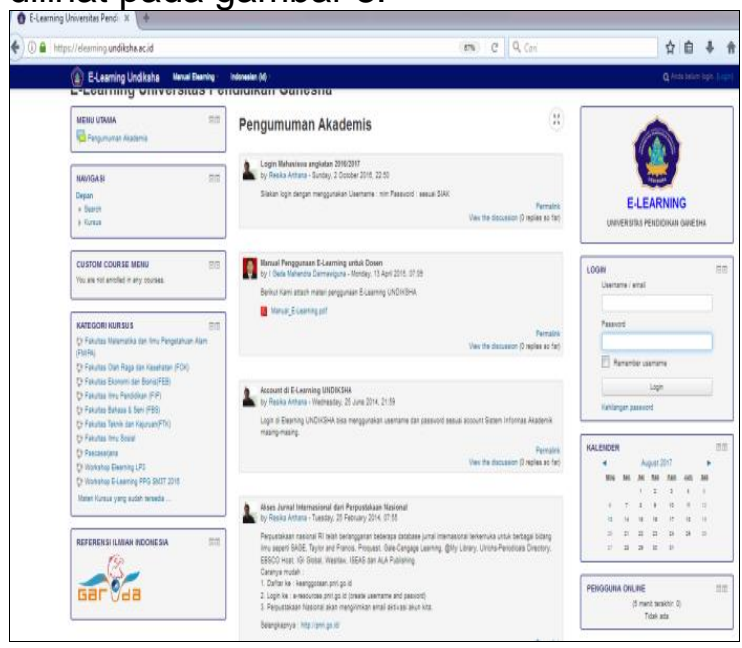

Gambar 3. Tampilan home

Setelah mahasiswa berhasil login ke sistem, maka mahasiswa diwajibkan untuk mencari kategori fakultas, kemudian ke kategori jurusan untuk melihat mata kuliah yang ada pada sistem. Untuk lebih jelasnya bisa dilihat pada gambar 4 .

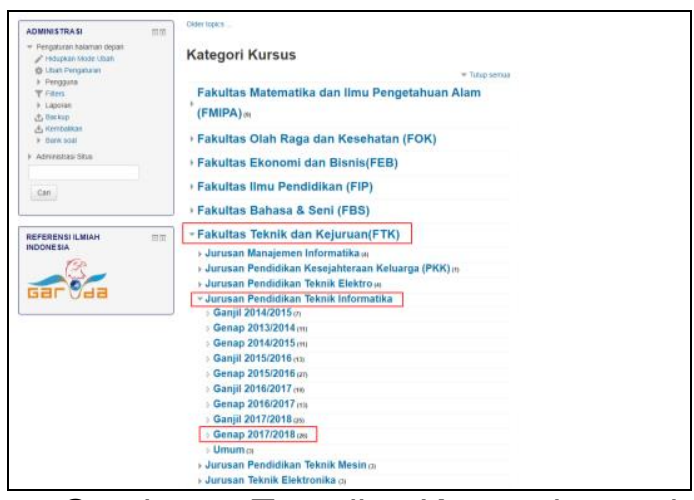

Gambar 4. Tampilan Kategori materi setiap fakultas

Mahasiswa diwajibkan memilih course yang ingin diikuti, misalnya dalam hal ini adalah Kuliah Kurikulum dan Pengajaran (gambar 5). 


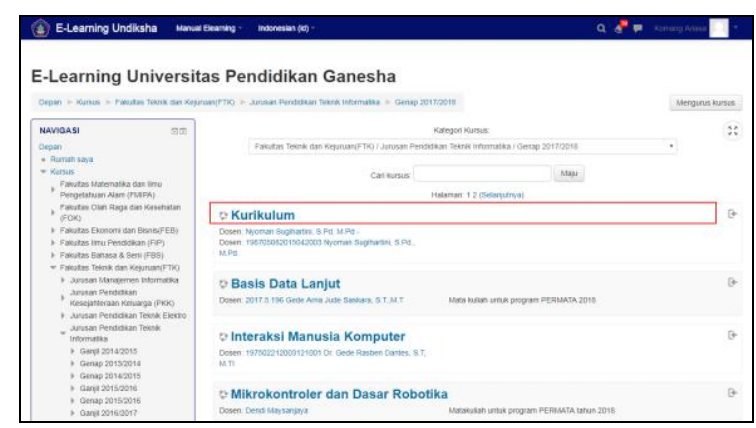

Gambar 5. Tampilan Kategori materi perkuliahan di jurusan

Setelah berhasil bergabung kedalam matakuliah misalnya Kurikulum dan Pembelajaran, mahasiswa akan mulai belajar menggunakan sistem MIE yang dalam hal ini dikemas dalam bentuk pembelajaran $\mathrm{PjBL}$.

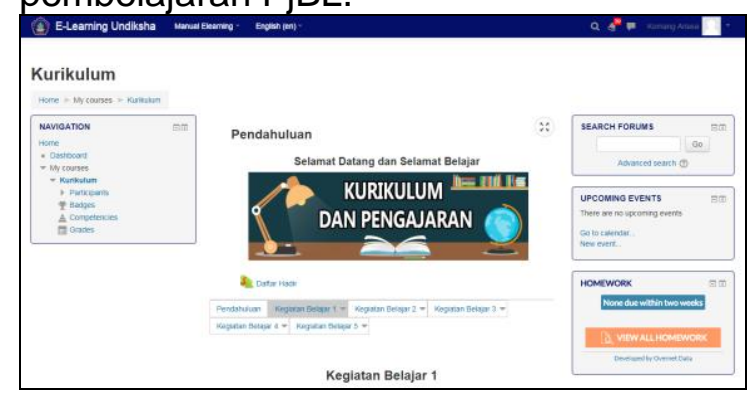

Gambar 6. Tampilan MIE Kurikulum dan Pengajaran

Secara lebih detail, terdapat beberapa aktivitas mahasiswa yang dapat dilakukan dalam elearning, yaitu sebagai berikut.
a. Melihat aktivitas dan mengikuti suatu pelajaran
b. Mengikuti semua langkah-langkah pembelajaran dengan model pembelajaran Project Based Learning $(\mathrm{PjBI})$.
c. Mengambil materi serta video tutuorial (jika ada) dari setiap kegiatan belajar.
d. Melihat dan mengumpulkan tugas yang di upload pada link tugas.

e. Melakukan diskusi dan forum untuk membahas proyek, tugas, ataupun materi yang sedang dibahas/ belum dimengerti.

f. Melihat nilai mahasiswa dan aktifitas pembelajaran lainnya.

\section{Mengikuti Pembelajaran Berbasis Model Pembelajaran Project Based Learning (PjBL)}

MIE Kurikulum dan Pembelajaran ini menggunakan langkah-langkah model pembelajaran Project Based Learning (PjBL) dengan tujuan agar peserta didik terdorong lebih aktif dalam belajar dan peran dosen hanya sebagai fasilitator, mengevaluasi produk hasil kerja peserta didik yang ditampikan dalam hasil proyek yang dikerjakan. Pada elearning menggunakan sistem pembelajaran tuntas sehingga mewajibkan mahasiswa menyelesaikan aktivitas ataupun kegiatan belajar terlebih dahulu untuk melanjutkan ke tahap pembelajaran berikutnya. Keterangan kegiatan belajar yang berwarna putih menandakan tahapan pembelajaran sedang dibuka dan wajib diselesaikan terlebih dahulu. Sedangkan keterangan kegiatan belajar yang berwarna abu-abu menandakan kegiatan belajar sedang terkunci dan mewajibkan Anda untuk menyelesaikan kegiatan belajar sebelumnya. Berikut adalah contoh beberapa kegiatan yang harus diselesaikan mahasiswa.

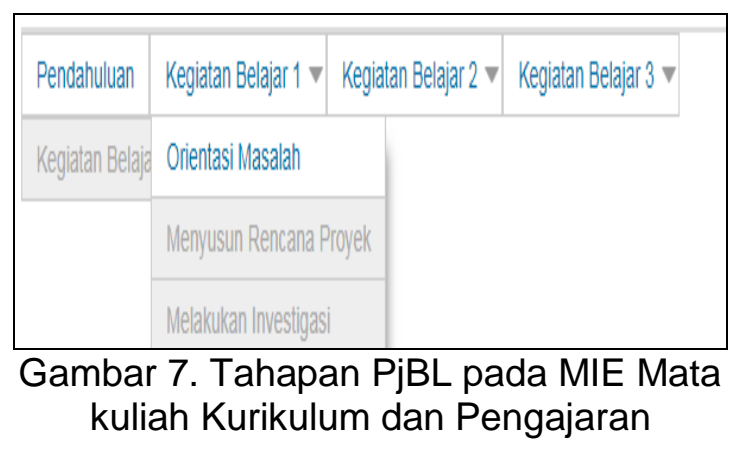

Pembelajaran dengan PJBL memiliki 6 sinak diantaranya: 1). Orientasi masalah, 2). Menyusun rencana proyek, 3). Melakukan investigasi, 4). Merencanakan laporan, 5). Presentasi laporan, 6). Evaluasi.

\section{Tahap Orientasi Masalah}

Mahasiswa mengamati atau menganalisis suatu permasalahan yang diberikan, kemudian mengikuti petunjuk dosen. Setelah menyelesaikan orientasi masalah, 
mahasiswa wajib checklist box yang sudah tersedia pada mata pelajaran EModul. Perhatikan gambar berikut ini sebagai contoh ceklist tahap-tahap pembelajaran lebih jelas.

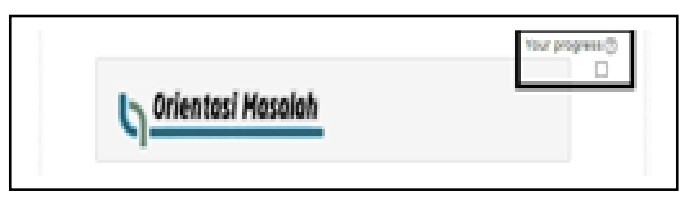

Gambar 8. Fase Orientasi masalah

\section{Menyusun rencana proyek}

Kegiatan yang dilakukan yaitu merencanakan kegiatan kelompok. Setelah membaca proyek yang diberikan dosen, maka selanjutnya mahasiswa wajib melakukan checklist box yang sudah tersedia untuk melanjutkan ke tahap berikutnya

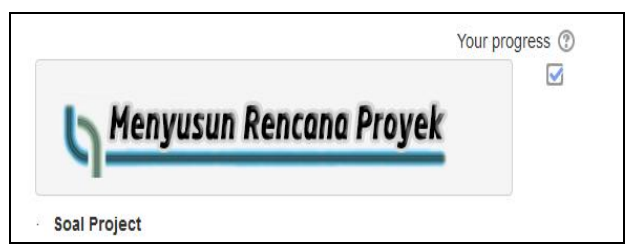

Gambar 9. Fase Menyusun Rencana Proyek

\section{Melakukan investigasi}

Mahasiswa melakukan investigasi dengan membaca materi pelajaran dan menonton video pembelajaran. Setelah selesai membaca dan menonton media pembelajaran, mahasiswa melanjutkan ke tahap berikutnya. Mahasiswa wajib melakukan checklist box yang sudah tersedia untuk melanjutkan ke tahap berikutnya.

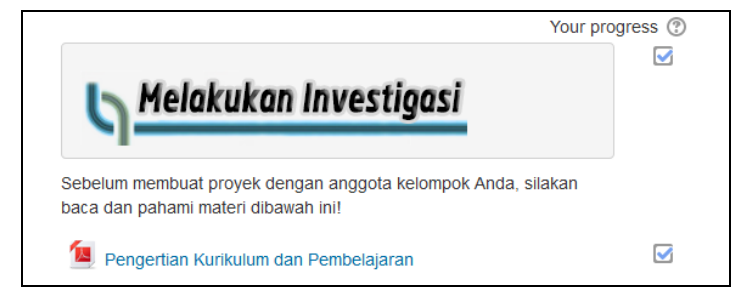

Gambar 10. Fase Investigasi
Mahasiswa melakukan penyusun laporan hasil investigasi dan wajib melakukan checklist box yang tersedia untuk melanjutkan ke tahap berikutnya. Setelah selesai, kemudian mahasiswa melakukan upload hasil proyek pada sistem.

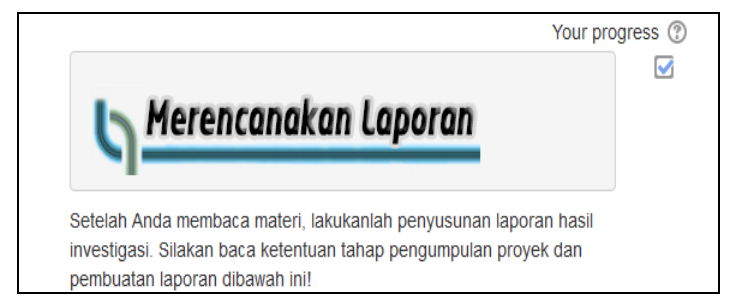

Gambar 11. Fase Merencanakan Laporan

\begin{tabular}{|c|c|c|}
\hline \multicolumn{3}{|c|}{$\begin{array}{l}\text { Uploadla laporan jika sudah selesai pada file pengumpulan } \\
\text { tugas. }\end{array}$} \\
\hline $\begin{array}{l}\text { Ul Upload Laporan Kelompok Proyek } 1 \\
\text { 启 Forum Diskusi }\end{array}$ & & 0 \\
\hline $\begin{array}{ll}\text { Gambar } & 12 . \\
\text { kelompok }\end{array}$ & Upload & \\
\hline
\end{tabular}

\section{Presentasi laporan}

Mahasiswa melakukan presentasikan laporan kegiatan proyek di depan kelas. Pada elearning dilengkapi pula dengan forum/ diskusi hasil proyek.

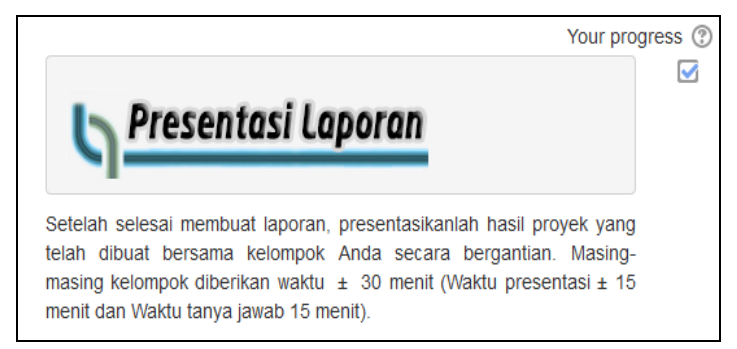

Gambar 13. Fase Presentasi Laporan

\section{Evaluasi}

Mahasiswa mendokumentasikan masukan-masukan dosen yang berhubungan dengan proyek. Setelah itu dilakukan evaluasi berupa kuis, untuk cara menjawab soal-soal tes dapat diperhatikan pada gambar 14 .

\section{Merencanakan laporan}




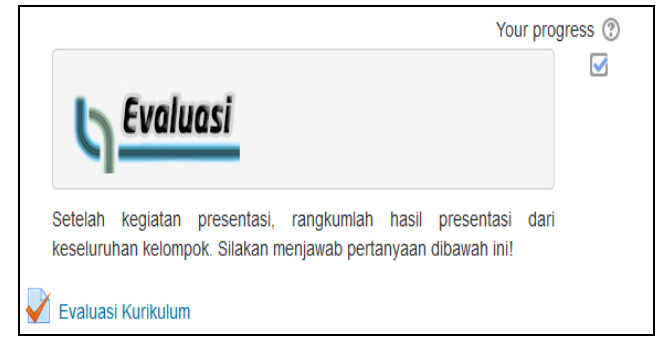

Gambar 14.Fase Evaluasi

\section{SIMPULAN DAN SARAN}

ADDIE sangat efektif digunakan sebagai salah satu model pengembangan sistem e-modul. Tahapan-tahapan ADDIE juga sangat sistematis sehingga dihasilkan produk yang siap digunakan serta memenuhi standarisasi pengujian pengembangan produk. Pengembangan Media Instruksional Edukatif (MIE) mata kuliah Kurikulum dan pengajaran sebagai salah satu inovasi dalam perkuliahan, telah diimplementasikan pada web elearning undiksha dengan alamat http://elearning.undiksha.ac.id. MIE yang dikembangkan dalam penelitian ini berbasis CAI (computer assisted instruction) yang artinya jika mahasiswa belum menyelesaikan satu kegiatan belajar, maka kegiatan belajar berikutnya di-invisible oleh sistem. Setiap kegiatan belajar dikemas dengan mengikuti sintak proses pembelajaran project based learning. Pembelajaran dengan PJBL memiliki 6 sinak diantaranya: 1). Orientasi masalah, 2). Menyusun rencana proyek, 3). Melakukan investigasi, 4). Merencanakan laporan, 5). Presentasi laporan, 6). Evaluasi.

Tahap penelitian berikutnya yang dilakukan adalah melakukan pengujian sistem e-modul ke beberapa judges, diantaranya ahli isi, media dan design pembelajaran. Kemudian dilakukan uji lapangan untuk mengetahui efektivitas penggunaan MIE dalam perkuliahan Kurikulum dan Pengajaran serta pengambilan respon Mahasiswa.

\section{UCAPAN TERIMAKASIH}

Tim Peneliti mengucapkan terima kasih yang sebesar-besarnya kepada
DRPM Dikti atas pembiayaan penelitian ini.

\section{DAFTAR PUSTAKA}

Adiputra \& Sugihartini. (2014).

Pengembangan e-Modul pada

Materi "Melakukan Instalasi

Sistem Operasi Jaringan

Berbasis GUI dan Text" untuk

Siswa Kelas X Teknik Komputer

dan Jaringan SMK Negeri 3

Singaraja. KARMPATI ISSN 2252-

9063, Volume 3, Nomor 1, Maret

2014.

http://pti.undiksha.ac.id/karmapati/fi les/vol3no1/3.pdf

Ali, Muhamad. (2009). Pengembangan

Media Pembelajaran Inetarktif

Matakuliah Elektromagnetik.

Jurnal Edukasi Vol.5 No 1, maret

2009, hIm 11-18.

http://journal.uny.ac.id/index.php/je

e/article/view/972/781 (Diakses

tanggal 10 Mei 2017)

Damarsasi, Soeprodjo, \& Saptorini.

(2013). Penerapan metode Inkuiri

berbantuan e-modul. National

Scientific Journal of Science

Volume 7 Nomor 2.

https://journal.unnes.ac.id/nju/index .php/JIPK/article/view/4420/3785

(Diakses tanggal 2 Juni 2017)

Haryoko, Sapto. 2009. Efektivitas

pemanfaatan Media Audio-Visual sebagai alternatif Optimalisasi

Model Pembelajaran. Jurnal

Edukasi Vol.5 No 1, maret 2009, hlm 1-10.

http://journal.uny.ac.id/index.php/je e/article/view/972/781 (Diakses tanggal 10 Mei 2017)

Kemendikbud. (2013). Model

Pembelajaran Berbasis Proyek

(Project Based Learning).

Jakarta: Kementrian Pendidikan

dan Kebudayaan. 
Riyadi, Selamet dan Kawaqibul Kamar. 2017. Efektivitas e-Modul Analisis Real pada Program Studi Pendidikan Matematika Universitas Kanjuruhan Malang. Supremum Journal of Mathematics Education (SJME), Vol.1, No.1, Januari 2017, pp. 31-40, e-ISSN: 2548-8163| p-ISSN: 2549-3639.

Sari, I. M. (2014). Perancangan Media Pembelajaran Matematika Sekolah Menengah Pertama Menggunakan Metode Computer Assisted Instruction Berbasis Web. Pelita Informatika Budi Darma, 46 - 50.

Suarsana, I M., \& Mahayukti, G. A. (2013).

Pengembangan E-modul Berorientasi Pemecahan Masalah untuk Meningkatkan Keterampilan Berpikir Kritis Mahasiswa. Jurnal Nasional Pendidikan Teknik Informatika (JANAPATI), 193-200.

Sugihartini, Nyoman. 2016. Strategi Pembelajaran (Pendekatan pembelajaran inovatif disertai dengan Aplikasi Pembelajaran Bidang Teknologi Informasi dan Komunikasi). Singaraja: Undiksha Press.

Trisiana dan Wartoyo. 2016. Desain pengembangan model pembelajaran pendidikan Kewarganegaraan melalui addie model untuk meningkatkan Karakter mahasiswa di universitas slamet riyadi Surakarta. Jurnal http://jurnal.fkip.uns.ac.id/index.php /progresif/article/download/9728/71 82

Undang-undang No 20 Tahun 2003.

Sistem Pendidikan Nasional. http://s3.amazonaws.com/academi a.edu.documents/35241782/Undan g-
Undang No. 20 Tahun 2003 tent ang Sistem Pendidikan Nasional. pdf?AWSAccessKeyld=AKIAIWO WYYGZ2Y53UL3A\&Expires $=1497$ 078750\&Signature $=$ Lk4143VUz0hU 09WmcUTljIU9LOU\%3D\&response -content-

disposition=inline $\% 3 \mathrm{~B} \% 20$ filename \%3DUNDANG-

UNDANG REPUBLIK INDONESI A NOMOR 2.pdf (Diakses tanggal 20 Mei 2017) 